YEARBOOK

of ANTITRUST

and REGULATORY

STUDIES

www.yars.wz.uw.edu.pl
Peer-reviewed scientific periodical, focusing on legal and economic issues of antitrust and regulation. Creative Commons Attribution-No Derivative Works 3.0 Poland License.

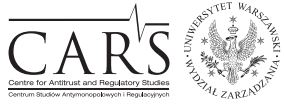

Centre for Antitrust and Regulatory Studies, University of Warsaw, Faculty of Management www.cars.wZ.uw.edu.pl

\title{
Evolving Dynamics in Competition Law: A GCC Perspective
}

\author{
by
}

Nora Memeti*

\section{CONTENTS}

I. Introduction

II. Competition advocacy: a helping hand

III. Competition laws of GCC Member States

1. Qatar and its straightforward law

2. Kuwait and its startups

3. The United Arab Emirates and its unusual competition law

4. Oman: an independent center on competition law

5. Bahrain and its short complementary law

6. Saudi Arabia: the best example in the region?

IV. GCC competition law: an avenue for the future?

\section{Abstract}

This article examines the Competition Laws of the Members States of the Gulf Cooperation Council (GCC). It examines their content, puts all of them under general scrutiny from their enactment until today and compares their basic features to other (developed) competition law jurisdictions, such as EU Competition Law and US Antitrust Law.

The article argues the importance of the Advocacy principle in the region and the incentives international organizations (IOs) have induced so far for the development of Competition Law in the GCC Countries, including the link between trade and Competition Law.

* Dr Nora Memeti, Associate Professor of Law, Kuwait International Law School, Doha, Kuwait, ORCID: 0000-0001-6406-4781, e-mail: n.memeti@kilaw.edu.kw. Article received: 10 August 2019, accepted: 30 September 2019. 
In today's economy where online giant companies dominate, where the restrictive conduct among separate independent commercial entities grows immensely, and where mergers do not identify formal state borders, the need for global Competition Law enforcement is indispensable. Therefore, in order to be part of the global competition world, a creation of GCC Competition Law may be considered progressive and advantageous. The article argues the purposes and motivations why such awareness is desirable and provides legislative and normative recommendations on how to accomplish this endeavor.

\section{Resumé}

Cet article examine les lois sur la concurrence des États membres du Conseil de coopération du Golfe (CCG). Il examine leur contenu, les analyse d'un point de vue général depuis leur adoption jusqu'à aujourd'hui et, dans une certaine mesure, les compare aux autres juridictions (les plus développées notamment), telles que la législation européenne sur la concurrence et la législation antitrust américaine. Larticle fait valoir l'importance du principe du plaidoyer dans la région, les initiatives que les organisations internationales (OI) ont prises jusqu'ici pour le développement du droit de la concurrence dans les pays du CCG, notamment le lien entre commerce et droit de la concurrence. Dans l'économie d'aujourd'hui où les géants de l'Internet dominent et les comportements restrictifs entre entités commerciales indépendantes distinctes se multiplient et les fusions n'identifient pas les frontières officielles des États - la nécessité d'appliquer le droit mondial de la concurrence est indispensable. Par conséquent, une création du droit de la concurrence du CCG peut être considérée comme une solution progressive et avantageuse. Larticle fait valoir les buts et les motivations pour lesquels une telle prise de conscience est souhaitable et fournit des recommandations législatives et normatives sur la manière dont cet effort doit être accompli.

Key words: competition law; GCC Member States; institutional framework; legislative framework.

JEL: K21

\section{Introduction}

The research on Competition Law, ${ }^{1}$ its adoption and particularly enforcement in developing Countries (Waked, 2008; Waked, 2014; Molestina, 2019) such as the Member States of the Gulf Cooperation Council (hereinafter: GCC), is a difficult and challenging task (Palacios-Lleras, 2010). The GCC

1 'Antitrust' and 'Competition Law' are used interchangeably hereinafter. 
Member States, namely Kuwait, United Arab Emirates (Emirates), Saudi Arabia (Saudi), Qatar, and Oman have all adopted Competition Laws during 2004-2014. Bahrain is the last country within the GCC to enact a Competition Law just last year, in 2018.

One of the reasons for adoption of Competition Laws in GCC countries has to do, among others, with policies of International Organizations (hereinafter: IOs) (Gerber, 2010; Evenett, Lehmann and Steil, 2000; Kennedy, 2018), including the World Trade Organization (hereinafter: WTO), and the International Competition Network (hereinafter: ICN). They have played an important role in providing awareness and assistance to developing countries, including the GCC. It is totally legitimate to ask whether enforcement is a real concern for countries other than developed ones (Molestina, 2019). Whereas GCC Member States experience similar linguistic, cultural and religious qualities, it is considered that drafting Competition Law at the GCC level on one hand, and the improvement of economic integration on the other hand, should be easier compared to, for example, the institutional and legislative hardship experienced at the EU level. Although extensively discussed in conditions of an open market, and due to incomes originating from oil production in particular, still, the idea of creating a supranational institutional infrastructure of competition law at the GCC level looks distant (Fox, 2015).

This paper is divided into three parts. In the first part, the importance of Competition Advocacy will be discussed. The second part will provide an overview of the separate national Competition Laws of all GCC Member States, covering the main three pillars of competition law namely Anti-competitive Agreements, Abuse of a Dominant Position and Mergers. The institutional infrastructure and the applicable sanctions will be partially mentioned here. The last part examines potential benefits from the creation of competition law at the GCC level. The paper suggests potential inter-governmental organs to be shaped based on a common legislative framework such as the ones in the EU. These organs may be endowed with supranational powers and apply basic principles of transparency and impartiality when placing GCC companies under scrutiny. Due to its limited scope, this article does not address state aids or subsidies. In terms of methodology, this article applies the analytical, comparative and descriptive methods, including discussions of relevant case law.

\section{Competition advocacy: a helping hand}

In circumstances where GCC countries have already adopted respective competition law legislations and are facing challenges in their practical 
implementation, this article is a proponent of competition advocacy as a helping hand in the process.

Competition advocacy is generally defined as a notion covering all activities a competition authority is intending to undertake in order to promote competition, apart from those that involve enforcement of the law (International Competition Network, 2002, p. 25). The ICN states that competition advocacy is a soft law conducted by a competition authority in order to promote a competitive environment (International Competition Network, 2002, p. 25; Rakic, 2016, pp. 111-132). During the advocacy process, the Competition Authority is the one to assess and agree on the most important steps to be taken as necessary for the enhancement of the whole process. This mainly starts with the establishment of an independent authority. So far, Oman is the only example within GCC of having established an independent Center for Enforcement of Competition Law separate from the Ministry in charge.

When listing the preconditions of Competition Law adoption and enforcement, Professor Gal makes an analogy with the main ecological needs such as the soil, sun, water and pesticides (Gal, 2004). Therefore, she states that the main preconditions for competition law to bloom will be the socio-economic ideology as well as institutional, organizational, and political qualifications. $^{2}$

In order to be able to provide a comparative analytical approach to the separate competition laws of GCC countries, the main pillars of EU Competition rules (Jones and Sufrin, 2016; Wish and Bailey, 2018) and US Antitrust law (Elhauge, 2017; Lundqvist, 2014; Hawk, 2013) will be observed. There are three reasons to do so: first, because they are generally considered more advanced; second, because GCC countries' competition rules are shaped drawing inspiration from them; and third, they may represent notable models for designing GCC Competition Law.

Starting with the EU, European Competition rules are included in Chapter I, Title VII of the Treaty on the Functioning of the EU (TFEU) (Foster, 2016). ${ }^{3}$ EU Competition Law stands on three main pillars including Anticompetitive Agreements, Abuse of a Dominant Position and Mergers (Jones and Sufrin, 2016). The first two pillars are covered within Articles 101-109 TFEU, the third pillar, namely Merger, is regulated only as a secondary legal source so far, not included in the TFEU. All agreements, decisions by associations and concerted practice deemed restrictive for competition and affecting the trade between Member States are prohibited (Doleys, 2012; Colino, 2017; Odudu, 2010). ${ }^{4}$

2 Professor Gal, specifies that these conditions are country- specific and must stay so.

3 Articles 101-109 Treaty on the Functioning of the European Union.

${ }^{4}$ First pillar: Article 101(1) TFEU. The following paragraph of this article declares void those caught by Article 101(1). And the third paragraph of Article 101 provides exemptions if four conditions are fulfilled. 
One or more companies enjoying a dominant position in the common market or a substantial part thereof, and which may affect trade between Member States, is prohibited from abusing such position (Behrens, 2015; Akman, 2008, 2009, 2017). ${ }^{5}$ Mergers are primarily regulated by a Regulation (EUMR) referring to 'concentrations with EU dimension' (von Koppenfels, 2015; Drauz, Chellingsworth and Hyrkas, 2009). ${ }^{6}$ Many other regulations, directives, soft laws (such as Notices, guidelines from the secondary legislation) and particularly case law have been developed in the sixty years of the existence of EU Competition Law.

For a long time, advocacy of EU Competition Laws in the GCC region has been accomplished implicitly (and primarily) through Egypt, which has traditionally been influenced by French jurisprudence (Ghoneim, 2002, p. 46). ${ }^{7}$

On the other side of the Atlantic Ocean, although the first federal antitrust statute was adopted in Canada in 1889, a year before the Sherman Antitrust Act was adopted in the US; GCC countries have generally followed US Antitrust law (Collins et al., 2003). With the adoption of the Sherman Act $^{8}$, US Antitrust Law was conceived with its main aim to control anti-competitive acts of business firms (Fox, 2013; Kovacic and Shapiro, 2000). Today, this field is known as Competition Law and Policy, as underlined by Professor Fox (Fox, 2013). Analogous and diverse principles, aims and objectives characterize the most developed competition laws in the EU and the US regarding both substantive and procedural rules. (Waked, 2014; Petersmann, 1999; Hyman, 2012). GCC Member States have in particular absorbed the penalty system embodied in US Antitrust Law, particularly the criminalization of cartels (Whelan, 2014). However, the substantive rules, including the three main pillars, are mainly transplanted from EU Competition Law. Noting the objectives and goals of the separate competition laws of GCC community, in general, similarities are obvious regarding the US pro-freedom for business aim and dissimilarities with EU Competition Law, considered to be more aware of open-market considerations (Fox, 2006, 211) ${ }^{9}$ However, it is logical that competition law, although derived from the most developed systems, cannot be understood in the same way in developing countries. In particular, the cultural perspective plays a key role in that respect. Dabbah (2010) underlines that the legal culture of a particular developing country is of vital importance linked closely to its population.

5 Second pillar: Article 102 TFEU.

6 Third pillar: mergers and acquisitions regulated under Regulation No 139/2004 of 20 January 2004 on the control of concentrations between undertakings (the EC Merger Regulation).

7 See also Omani's example elaborated below on the issues of Competition Advocacy.

8 15 U.S.C. $\S \S 1-7$ (1890).

${ }^{9}$ Find more below at the third part under the Separate Competition Laws of GCC Countries. 
There are some specific advocacy developments in the GCC as well. During the latest Annual Conference organized by the Kuwait International Law School in Kuwait (KILAW), representatives of the Omani Competition Council introduced a project on Competition Law advocacy in Oman (Hamouda, Barashidi, 2019). The project was divided into two parts, the first part presented was 'what and how to learn from US Antitrust Law', which, based on the reviewers will take place in the following two years. The second part was perceived to be the 'lessons from EU Competition Law'. The authors stressed various aspects of EU Competition Law and US Antitrust Law, in particular including the aims and objectives, the relation with consumer welfare principle, the penalties and fines, etc.

An additional attribute related to advocacy is the impetus of international organizations such as the ICN and the WTO. Whereas the ICN is an association of competition authorities aiming for the promotion and convergence of domestic laws (in particular procedural matters of merger control); the WTO is an intergovernmental IO promoting a cooperative agreement about trade between different governments. ${ }^{10}$ Mario Monti's speech noted their relevance when stating that 'EU Governments must follow the European example by adopting their national merger laws according to the ICN recommendations'. ${ }^{11}$ This article suggests that this note should not be pursued only by European States and certainly not only within mergers. There is nothing bad using the invented wheels and there is no need to re-invent them also, (Whish, QC, Gest lecture at the Latvian Law Institute, 2014). So far, from the GCC countries, Kuwait, Saudi Arabia and Qatar are members of the ICN. ${ }^{12}$ The compliance consideration and the aim for convergence should stay on top of other requirements for membership in different IOs. Although ICN recommendations stand as soft laws only, they provide example of best practices and accepted principles shared among members (Bode and Budzinski, 2005).

The WTO on the other hand, behaves analogously to the EU which constantly encourages EU Member States to enact consistent and coordinated competition laws. ${ }^{13}$ Parallel awareness can serve all GCC countries that are

10 See the WTO Agreement and the relevant Annexes, www.wto.org/english.

11 SPEECH 04/449 European Commissioner for Competition International Antitrust A Personal Perspective by Mario Monti, delivered at Fordham Corporate Law Institute, New York, 7 October 2004. Retrieved from: http://europa.eu.int/rapid/pressReleasesAction.do?r eference $=$ SPEECH $/ 04 / 449 \&$ format $=$ HTML $\&$ aged $=0 \&$ language $=$ EN \& guiLanguage $=$ en (25.03.06).

12 See at https://www.internationalcompetitionnetwork.org/about/.

13 See at: https://www.wto.org/english/tratop_e/comp_e/comp_e.htm, Syria may be considered as the example to illustrate how accession to the World Trade Organization (WTO) was conditioned upon the country meeting several requirements. One of these requirements 
members of the WTO. For the record, Qatar and the UAE were GATT contracting parties and original WTO members; Oman joined the WTO in 2000 and Saudi Arabia in 2005. Kuwait is a WTO original member as a GATT contracting party since 1963; Bahrain also is a WTO original member as a GATT contracting party since $1993 .{ }^{14}$

Finally, trade is another aspect closely related to the advocacy principle. ${ }^{15}$ GCC Member States are actively engaged in national and particularly international trade, mainly in the export of oil and more than $80 \%$ in import in all other industries. ${ }^{16}$ Since trade and competition in the market have always been considered as two sides of the coin, businesses must be aware of both (Fox and Healey, 2013, p. 769). If jurisdictions transplant similar norms within competition law, countries may benefit more from trade (Fox and Healey, 2013, p. 769). However, this does not stand as an absolute true. 'Copy-paste' rules and principles or legal transplants never function efficiently without due regard to specific circumstances of each national jurisdiction. ${ }^{17}$ As Professors Fox and Gal write, developing countries deserve a competition law that fits the facts of their markets and responds to their conditions and needs (Gal and Fox, 2015, p. 296). They add that, developing countries deserve a law so designed so the public will find it understanding and legitimate.

Based on different laws related to trade, other than competition law, the governments of GCC countries have reached agreements to grant their citizens and companies certain advantages. ${ }^{18}$ For instance, Oman and the Emirates are considered to be the fastest growing economies in 2019 according to a report by the Institute of International Finance (IIF). ${ }^{19}$ For 2019, Oman's growth has also been predicted to reach 3.1 per cent, while Bahrain's real GDP is expected to grow 2.4 per cent, Saudi Arabia's 2 per cent, and Kuwait's 0.4 per cent. ${ }^{20}$ Omani regulations prescribe that GCC nationals have the right

concerned changes to Syria's economic laws and introducing a specific Competition Law domestically, see more Dabbah, 2010; Waked, 2016.

14 See WTO web site available at: www.wto.org/english. https://www.wto.org/english/ thewto_e/gattmem_e.htm (1.08.2019).

15 The unified Economic Agreement between the countries of the Gulf Cooperation Council, available at www.worldtradelaw.net/fta/agreement/gccfta.pdf

16 See www.credendo.com/country-news/economic-developments-six-gcc-countries, see also, International Monetary Fund, Gulf Cooperation Council, Trade and Foreign Investment-Keys to Diversification and Growth in the GCC. 2018.

17 On legal transplants see Watson, 1994.

18 The Economic Agreement of 2001, see more at: www.gcc-sg.org.

19 https://gulfbusiness.com/uae-oman-fastest-growing-economies-gcc-report/.

20 Despite the UAE's predicted growth over last year, IIF analysts suggested growth would slow to 2.7 per cent in 2020 . They added that they expect the country's nominal GDP to increase from Dhs1.59 trillion (\$434bn) in 2018 to Dhs1.63 trillion (\$458bn) in 2020. 
to buy residential, industrial and commercial properties, but not agricultural properties. $^{21} 1,038$ Gulf nationals purchased property in the Sultanate in 2018, compared to 855 during 2017.22 Same year, Qatar enacted two national laws, enabling GCC nationals to conduct business in Qatar and second, GCC companies to open branches in Qatar. ${ }^{23}$ GCC nationals, whether natural or legal persons, can engage in retail and wholesale trade in Qatar under some conditions. ${ }^{24}$ Such GCC companies will be treated like Qatari companies in accordance with the legislation in force. ${ }^{25}$

\section{Competition laws of GCC Member States}

This section examines the competition laws of each of the six GCC Members States. It reviews them chronologically based on the time of the adoption of the respective national competition law.

\section{Qatar and its straightforward law}

Qatar is the first country to be discussed in this paper, since chronologically it has the oldest competition law in the region. The Qatari Act for Protection of Competition and Prevention of Monopolistic Practices was adopted in 2006. ${ }^{26}$ This law was enacted in correlation with the Qatari accession to the WTO. ${ }^{27}$ It comprises of 20 articles, setting out in a straightforward way the prohibiting rules on Anticompetitive Agreements and practices between two or more

${ }^{21}$ See https://www.arabianbusiness.com/politics-economics/406604-number-of-gcc-investorsin-oman-property-rises.

22 See https://timesofoman.com/article/290567/Oman/GCC-nationals-buying-Oman-proper ties-rise.

23 Safwan Moubaydeen and Zaher Nammour Dentons, Mondaq.com, 201, Law No. 6 of 2017 amending some provisions of Law No. 7 of 1987 on Regulating the Conduct of Business Activities by GCC nationals in the State of Qatar (GCC Business Activities Law) and Law No. 7 of 2017 Permitting GCC Companies to Open Branches in Qatar (GCC Companies Branches Law).

${ }^{24}$ Article 2 of GCC Business Activities Law, see the details.

25 GCC Companies Branches Law, Article 1. Any problem of State action that unduly harms competition is left to political processes, which will be left out of this paper, see more: Crane, 2013.

26 Act No. 19 of 2006 for the Protection of Competition and the prevention of monopolistic practices. The terms 'Law' and 'Act' will be interchangeably used in the text.

27 The Agreement establishing the World Trade Organization and the multilateral trade agreements annexed thereto, and Decree No. 24 of 1995 ratifying Qatar's accession. 
companies and the Abuse of monopoly or collective dominance. ${ }^{28}$ For both violations the law provides for possible exemptions important for consumer welfare. ${ }^{29}$ The second general exemption, well known for the region, is the one applicable to all sovereign State undertakings and to all entities subject to State direction and supervision.

Qatari Competition Law establishes a system of a priori notification of mergers and acquisitions to the Committee for the Protection of Competition within the Ministry of Economy and Commerce. The latter is under a duty to issue a decision within 90 days. Exceptions from the rules regulating mergers which, in the Committee's view, assist economic development in a manner that compensates for any detriment to competition, are also regulated with this law. ${ }^{30}$

The Committee in charge of the implementation of the law exercises its duties ex officio or upon the request of any person aware of an anticompetitive conduct in collaboration with the Ministry of Commerce. ${ }^{31}$ Penalties for a breach of Qatari Competition Law include either a monetary fine, set between the minimum and maximum amount, or criminal punishment with a written permission from the Minister following the proposal of the Committee. In all cases, it is within the jurisdiction of the Courts to order the confiscation of any profit resulting from the contravention of competition rules. The closing provision lays down two main principles of liability: first, personal responsibility of the managers of legal entities involved in a violation if they were aware of the violating acts, and the failure to carry out their duties contributed to the offence, and second, joint liability of the legal entity for anticompetitive conducts undertaken by the employees in its name or in its interest. ${ }^{32}$

\section{Kuwait and its startups}

The Kuwaiti Competition Law was adopted in 2007 (one year later than the Qatari one) and entered into force in $2009 .{ }^{33}$ Two specific bylaws accompanied

28 Act No. 19 of 2006 for the Protection of Competition and the prevention of Monopolistic Practices, articles 3 \& 4. Regarding 'Abuse' see in general terms also: Palacios-Lleras, 2010.

29 Act No. 19 of 2006 for the protection of Competition and the prevention of monopolistic practices, articles $5 \& 6$; In the United States, the concern for economic welfare is central also, see more: Kaplow, 2011, p. 693. See more general also: Crandall and Winston, 2003.

30 Act No. 19 of 2006 for the Protection of Competition and the prevention of Monopolistic Practices, Article 10 \& 11.

31 Ibidem, Articles 7-9.

32 Act No. 19 of 2006 for the protection of Competition and the prevention of monopolistic practices, Article 18.

${ }^{33}$ Law No. 10 for the year 2007, Regarding the Protection of Competition, as amended by the Law No. 2 of 2012. 
the Law, the first adopted in $2009^{34}$ followed by the second in $2015 .{ }^{35}$ The Kuwaiti Competition Law repealed existing provisions in the Commercial Code dealing with anti-competitive behavior. ${ }^{36}$ However, the New Company Law of 2016, in part VII, elaborates how the process of mergers should be conducted in Kuwait. ${ }^{37}$ It can be argued that in Kuwait, and in the GCC in general, competition law is seen as an important part of commercial law (particularly the academia is of this opinion), under which mergers are regulated and organised, including therefore acquisitions or their combination as per the terms, mentioned therein (Al-Qaisi, 2019).

Structurally, the Kuwaiti Competition Law is divided into 5 parts and 28 Articles. Part one provides for general characteristics, such as definitions and characterizations of the main concepts. ${ }^{38}$ Part two consists of harmful practices and monopoly abuses. The law prohibits all agreements, contracts, practices considered harmful to competition, as well the abusive control of one or more undertaking. ${ }^{39}$ Similar to the Qatari Competition Law, two categories of exceptions are recognized, the first providing benefits to consumers and the second, for projects or utilities owned or managed by the State. ${ }^{40}$ The law expands its applicability to violations committed in Kuwait, as well as to those taking place abroad having harmful effects in the national market. The law established the Authority for Protection of Competition in order to reach the objectives and aims prescribed within, set under the jurisdictions of the Ministry of Economy. ${ }^{41}$ Companies engaging in mergers, except complying with the provisions of the Competition Law, must also comply with other laws, including Company Law, the Law on Capital Market etc. which were regulating mergers long before Competition Law was enacted. The Law on Capital Market is under the supervision of the Capital Market Authority (CMA), and prescribes a duty of prior notification of mergers and acquisitions. ${ }^{42}$ In certain circumstances, the parties are obliged to notify the

34 Council Regulation for implementation of Competition Law, No. 106.

35 Council Minister Regulation for implementation of Competition Law No. 994.

36 Kuwaiti Commercial Code, No. 68/1980.

37 Law No.1 of 2016 on Promulgating the Company Law.

${ }^{38}$ Law No. 10 for the year 2007, Regarding the Protection of Competition, as amended by the Law No. 2 of 2012, Articles 1-3.

39 Article 4 Law No. 10. See also KUNA, 2017, when the Kuwait Competition Authority for the first time made public announcements regarding several current investigations including meat, onion and fish importers engaged in price fixing activities. See more at: athttp://www. kuna.net.kw/ArticleDetails. aspx?id=2600420\&language $=$ en (30.07.2019).

40 Articles 5-6 Law No. 10.

41 For more, see the Competition Protection Agency, Ministry of Commerce. www.cpa. gov.kw.

42 Regulated under Law No. 7 of 2010 concerning the establishment of the Capital Market Authority and Regulating Securities Activities issued on February 21, 2010. Law No. 108 of 
Council of their intention to merge 60 days prior to the decisive day, and the failure to do so may result in penalties under Competition Law. The second burden that follows is to stay still until the Agency provides for a green light under the abovementioned jurisdictions, known as the standstill obligation principle. Based on one of the regulations issued in regard to the Law on Capital Market, if the proposed acquisition triggers the 35 per cent threshold of market control as mandated by Law No. 10 of 2007, the acquirer must notify the Authority for Protection of Competition. ${ }^{43}$

Practice shows that well-known platforms operate in Kuwait and that instances of interesting developments take place. For example, Delivery Hero Group Company (Delivery Hero), a leading European (German) global online food delivery, announced its acquisition of Carriage, a well known delivery platform operating in GCC. ${ }^{44}$ The ongoing operation was published in the media and the Competition Authority declared that the merger must be scrutinised by the Competition Authority. In 2015, Delivery Hero announced again in the media that it is acquiring another Kuwaiti food delivery company, operating throughout GCC, known as its direct competitor of Carriage under the name of Talabat. ${ }^{45}$ It was discussed at the time of the acquisition of Carriage, that it would be a natural step for Delivery Hero to strengthen their foothold in the GCC. Once more, the media discussed that these developments should be an incentive for Competition authoritiy to take a closer look at the acquisition in order to determine if this merger will have anti-competitive effect in the domestic market. The Authority in charge stated (again throught the media) that the acquisition of Carriage, which is already operating in Kuwait and other GCC countries, and the acquisition of Talabat (a competitor) by the same company may be harmful to competition in the online food delivery market and could potentially result in abusing its dominant position of these services. During this process, relevant parties should provide various corporate documents to the Market Capital Authority for revision, if requested so. Assuming the powers are in the hands of the Competition Authority, the Market Capital Authority can also require additional documents related to the practical and economic

2014 amending some provisions of Law No. 7, 2010, was issued on July 23, 2013. Law No. 22 of 2015 amending some provisions of Law No. 7, 2010, issued May 4, 2015.

43 Regulation of acquisitions, Regulation No. 7 of 2013, issued based on Law No. 7 of 2010 on Establishing a Capital Markets Authority and Regulating Securities Activities. Except the main law, two regulations have been adopted, one in 2014, Cabinet Decision No. 37/2014 which is the implementing Regulation of Federal Law of 2012, and Cabinet Decision No. 13/2016 which provides the ratios and the controls related to the application of Federal Law of 2012.

44 The details of the case are mentioned below in the part covering the development of GCC Competition Law.

45 Delivery Hero acquired Talabat, another Kuwaiti food delivery company operating throughout the GCC for around KWD 50 million (equivalent to around 150 million Euros). 
impact the acquisition may create. In the case of 'Delivery Hero', it remains to be seen which Authority will strech its powers to deal with the case (if one ever will). It is expected the outcome of the case to have detterent effect for other commercial entities in the local market, particularly to start-ups, although the Kuwaiti Government constantly encourages its citizens to be active in that direction (Ghura and Harraf, 2018). To sum up, if the watchdog 'barks', it will be marked as an important step toward enforcment procces and also a warning bell for other players in the future. One may be interested to see how the market will be defined, what is the impact of the merger in the market, are the violated procedural steps of Gun Jumping or/and standstill obligation be under scrutiny, should the undertaking-agency (platform) contracts including discriminatory provisions will be under investigation, etc. So far, (the not-well informed) consumers are of the opinion that Talabat and Carriage are strong local competitors, having no knowledge Delivery Hero holds all the strings.

Looking at sectorial development, the Kuwaiti financial market has emerged as the second largest market in the GCC between 2014 and 2018.46 The investment Banking Department announced that the number of transactions in Kuwait grew by $163 \%$ within merger and acquisitions. Based on the wellknown Financial Center 'Markaz', the dealings grew from 16 to 42 in the period between 2014 and 2018. These transactions are in particular important in the fields of food and beverage, telecommunications, education, and technology sectors.

Finally, as regards monetary fines, violators can be fined upto one hundred thousand Kuwaiti Dinars (equivalent to around three hundred thousand Euros) or an agreeable fee between the violator and the authority in charge, if the infringement is repeated. It is within the Authorities' discretional powers to also order the confiscation of the commercial activity or its restriction for a maximum of three years. In a country like Kuwait, where citizens experience one of the highest living standards, questions appear quite often such as: how important is the enactment of competition law (Denny, 2019) and is competition always good (Stucke, 2013). Consumers, if knowledgeable enough about the benefits enforcement of competition law may bring, are the one and only vehicle so far to ask for it (Vedder, 2006; Kovacic, 1997, p. 404). Since in many countries both competition law and consumer law come together, including the US, when consumer protection is at stake, the same routine applies in Kuwait as well (Leary, 2005). Qaqaya (2008) is very explicit when stating among others that competition between companies enhances consumer welfare by providing consumers with wider choices at competitive prices. ${ }^{47}$

\footnotetext{
46 See more at: Investment Banking Department at Kuwait Financial Centre Markaz.

47 The effects of anti-competitive business practices on developing countries and their development prospects.
} 


\section{The United Arab Emirates and its unusual competition law}

The United Arab Emirates enacted a Federal Law on Anticompetitive and Monopolistic Practices in 2012 (hereinafter the Anticompetitive Law) ${ }^{48}$ The Law contains 33 Articles regulating competition in all commercial sectors.

It is worth mentioning that the Law on consumer protection prescribes only monetary fines although it stipulates that for acts contrary to fair competition, a criminal prosecution can be initiatied with the Minister's approval (see more below) ${ }^{49}$

The Anticompetitive Law entered into force in 2013 and has been characterized as unusual (Fox and Trebilcock, 2013) since the legislator was to introduce an opening provision clarifying the policy behind the Competition Law, an approach that may help institutions related to its judicial review. A Committee, established on the basis of the Competition Law, and functioning under the supervision of the Ministry of Economy, is provided for as the relevant competition regulator in the country. The Committee was established recently (in 2018), and it remains to be seen how it will operate in practice..$^{50}$

The Law in a very broad manner elaborates competitive markets governed by market mechanisms in accordance with the economic freedom principle, prohibiting restrictive agreements that may lead to the abuse of a dominant position, controlling the operations within mergers and avoiding all that may prejudice, limit or prevent competition. ${ }^{51}$ The Competition Law includes specific rules with the objective of protecting consumers and small enterprises from anti-competitive conduct. Similarly to other jurisdictions, it includes restrictions such as price fixing, market sharing/ division and allocation, applying different conditions and the list goes on. The Law includes rules that prohibit undertakings from hampering competition and harming consumers and other competitors through the abuse of their dominant position. Through dominant position, undertakings are granted extra powers against their competitors, and based on EU practice, it can be concluded that special responsibilities will be attached. ${ }^{52}$ The Law provides that its provisions shall be enforced on all businesses in relation to their economic activities in the Emirates. The

48 Federal Law No. 4 of 2012 on anticompetitive and monopolistic practices, implemented on 27th October 2014 by adopting, with resolution of the Council of Ministers No. 37 of 2014.

49 Law No. 39 of 2014 on Consumer Protection.

50 Federal Law No. 4 of 2012 on anticompetitive and monopolistic practices, Articles 12 \& 13. In 2018, the Ministry established the committee and issued the anticipated guidance and forms to allow concerned parties to make merger clearance submissions to the Ministry.

51 Federal Law No. 4 of 2012 on anticompetitive and monopolistic practices Article 2 in correlation with Article 5.

52 Article 6 Law No. 4. 
Law may also be enforced against economic activities outside of the country that influence competition in the domestic market based on extraterritorial jurisdiction (Geradin, Reysen, and Henry, 2008; Svetlicinii, 2006). ${ }^{53}$

The list of abuses to the prejudice, limitation or prevention of competition is of an exhaustive nature as well. Although the Law does not determine the threshold, the Cabinet within the Ministry of Commerce enjoys discretional powers in this regard. The same freedom applies to mergers, for which based on the Law, a 30-day advance application is required. ${ }^{54}$ Before mergers take place, companies are required to seek approval from the Ministry of Economy in cases where the merger or acquisition is likely to restrict competition in the market or where the overall share exceeds $40 \%$ of the total transactions in the market. The Ministry of Economy will review such proposals and demand the increase or decrease of proportions of concentrations, as per the demands of the economy. ${ }^{55}$

The subjects of Emirates Anticompetitive Law are partially different from the above-mentioned jurisdictions, since the exception granted to the Government and its related entities is extended to enterprises operating in some business sectors, such as telecommunications, financial services, cultural activities, oil and gas, pharmaceutical products, postal services, electricity and water, and transportation. ${ }^{56} \mathrm{~A}$ de minimis clause covers small and medium enterprises, whose market share or whose agreements may have a negligible effect on the relevant market, fall into this category. ${ }^{57}$

Compared to the other GCC jurisdictions, the Emirates Anticompetitive Law is more specific in enumerating the entities to which exceptions apply. This includes: exemptions for Government-owned entities, the federal or local government; entities established by virtue of a decision or authorization granted by the federal government; entities wholly owned by the federal government or the local government; entities whose ownership by the Federal Government or a local government exceeds $50 \%$ or more and individual exemptions. ${ }^{58}$ The

53 See judgment of 9 November 1983, Case 322/810 Michelin v Commission, ECLI:EU:C:1983:313, para. 70 'A finding that an undertaking has a dominant position ... simply means that, irrespective of the reasons for which it has such a dominant position, the undertaking concerned has a special responsibility not to allow its conduct to impair genuine undistorted competition in the common market'.

${ }^{54}$ Federal Law No. 4 of 2012 on anticompetitive and monopolistic practices Articles 9-11.

55 See more in the official web-site of the Ministry of Economy under which the Commission for Protection of Competition is operating, https:/www.economy.gov.ae/English/Media-Section/ Pages/EventDetails.aspx? ItemId =122.

56 Annex. Sectors, Activities and Businesses Excluded from the Provisions of the Federal Law No. (4) of 2012 on the Regulation of Competition.

57 Ibid, the last paragraph of Article 5.

58 Federal Law No. 4 of 2012 on anticompetitive and monopolistic practices, Article 4, Article 14 and Appendix On sectors, activities and businesses exempted from the provisions of Federal Law No. 4 of 2012 On the Regulation of Competition. 
new Law provides severe penalties, unprecedented in the country, which range from AED 500,000 up to AED5 million (between around one hundred and twenty thousands Euros to one million and one hundred and twenty thousand Euros).

In cases of judicial review, the court may, upon conviction, order a business to be closed for a period of 3 to 6 months. ${ }^{59}$ With respect to criminal proceedings, as mentioned above in relation to Consumer Protection Law, the Emirates Anticompetitive Law stipulates that the Minister's approval is required for initiating any criminal prosecution of acts contrary to the Law. The Law also authorizes the Minister of Economy to reconcile any contravention of the Law before a criminal case is transferred to the Criminal Court in return for a settlement amount equivalent to no less than double the minimum fine. In 2018, the Committee also joined the ICN as mentioned above, one of the greatest networks within Competition Law. ${ }^{60}$

\section{Oman: an independent center on competition law}

The Omani Competition Law ${ }^{61}$ incudes five chapters allocated in 30 articles, covering many activities related to production, trade, services, and any other economic or commercial activity practiced inside and outside Oman. With regard to the first pillar, the law distinguishes two groups, monopolistic agreements and restrictive agreements. Whereas the first category is about those creating or maintaining a monopoly over production, import, distribution etc., being able to negatively affect the market, the second category is more about agreements concluded between two or more companies with a purpose to prevent, eliminate or distorts competition. ${ }^{62}$ The second and third pillars are covered with similar provisions to the above-mentioned jurisdictions, although in this country the threshold for clearance goes upto 50 per cent. ${ }^{63}$ Again one should examine the applicable exceptions compared to other GCC jurisdictions and the block exemptions granted to agreements or business activities that entail consumer protection and benefit in cases specified by the law. The Law of 2014 states that the same Authority deals with the enforcement of both

59 All competition court cases have been granted the advantage of expedited cases and the Law allows for interim relief and temporary injunctions pending final court judgment.

60 See https://www.hoganlovells.com/en/publications/the-uae-competition-committee-hasfinally-become-operational-merger-control-in-the-uae-and-the-gcc-region (30.07.2019).

61 The Law for the Protection of Competition and Prevention of Monopoly, Royal Decree Bearing No. 67 of 2014.

62 Article 9 of the Law.

63 Articles 10 and 11 of the Law. 
Competition Law and Costumer Protection Law namely the Public Authority for Consumer Protection. ${ }^{64}$ Based on Omani Competition Law, the fines include criminal offences and monetary payments. The amount to be paid is the benefit gained calculated as a percentage of the annual sales.

In 2018 the Competition Protection and Monopoly Prevention Center was established based on Royal decree No. 2 of $2018 .{ }^{65}$ This was considered a huge step within the region. Its mission is to provide a healthy and informed competition regime in order for competitive markets and innovative businesses to grow within the country. Its objective is to ensure the application of the law so as to establish market rules and free prices. It should be emphasized that the center enjoys a separate legal personality as well as financial and administrative independence from the Public Authority for Consumer Protection. ${ }^{66}$ Compared to other jurisdictions, where the powers mainly remain in the hands of the Ministry of Commerce, Oman takes a progressive lead in this direction.

In 2014, Oman was registered among countries that have criminalized cartels ${ }^{67}$ and introduced civil penalties. ${ }^{68}$

\section{Bahrain and its short complementary law}

Bahrain was the fifth GCC country to adopt a separate competition law in 2018. The legal system in Bahrain, similarly to other GCC Member States, is part of the civil law tradition influenced by the Egyptian legal system (mainly based on French Law). The main legislation governing competition, the Law Prohibiting the Restriction of Competition and Protecting Personal Data, was adopted in 2018. As the title of the Law suggests, it covers both competition and personal data law. ${ }^{69}$ The Law consists of 'only' 11 short articles

64 Articles 12-17 of the Law, see also Akman, 2010.

65 Competition Protection and Monopoly Prevention Center, Oman - www.cmc.com; Royal Decree, Official Gazette, Issue No. 1226, No. 2/2018.

66 The first awareness workshop was held on December 18, 2018 and the second awareness workshop is scheduled to be held on October 2019.

67 Cartel activity implies the existence of an anticompetitive agreement, concerted practice or arrangement between competitors to fix prices, restrict output, divide markets or make rigged bids, see also OECD, Recommendation of the Council Concerning Effective Action Against Hard Core Cartels, C(98)35/final, 25 March 1998, [2(a)]. See also Whelan, P. (2014). The criminalization of European cartel enforcement: Theoretical, legal, and practical challenges. OUP Oxford.

68 See at: https://www.nortonrosefulbright.com/en/knowledge/publications/1c8cd600/thecriminal-cartel-offence-around-the-world (30.07.2019).

${ }^{69}$ Law No. 31 of 2018 Law prohibiting the restriction of competition and protecting personal data. 
prohibiting the restriction of competition, including monopolies, noting the manipulation of prices among undertakings and ambiguously touches upon mergers. In addition, it also briefly covers the scope and the responsibilities of a competition authority to be established.

However, it should be noted that restrictive agreements among commercial entities have been regulated earlier under the civil code. ${ }^{70}$ Particular rules against unfair competition and monopolistic practices are included in the Commercial $\mathrm{Code}^{71}$ and other applicable provisions are stipulated within the Consumer Protection Law, which contains a specific chapter named 'Rules of Competition and Monopoly and Manifestations of Breach of their Rules'.72

In contrast to other GCC jurisdictions, Bahrain is known for its sectorial regulation. In particular, as part of it accession to the WTO in $2003^{73}$, the telecommunication market was liberalized by promoting effective and fair competition under which the Telecommunication Regulatory Authority (TRA) was established. One of the main reasons to do so was to end the monopoly of Batelco, a company enjoying a dominant position for more than two decades. ${ }^{74}$ The telecommunication sector is a solid basis on which a better general Competition Law is to be built in Bahrain.

\section{Saudi Arabia: the best example in the region?}

Saudi Arabia is the only country in the region that has adopted two laws on the protection of competition so far. The first Competition Law was enacted in 2004, and amended in 2014, including only 21 articles. The current Law was enacted on 29 March 2019 and it should enter into force by the end of September $2019 .{ }^{75}$ It is expected that within 180 days from the publication of the Law in the relevant Official Gazette, implementing regulations will be issued. The New Competition Law mandates also the establishment of an independent Authority in charge of the application of the Law, operating under

70 Law No. 19 of 2001 of Civil Code of Bahrain.

71 Commercial Code No. 7 of 1987, Bahrain.

72 Law No. 35 of 2012 on the Consumer Protection, see also Crandall and Winston, 2003.

${ }^{73}$ Law No. 48 of 2002, available at telecommunication Regulatory Authority website, www. tra.org.bh.

${ }^{74}$ In 2003, the Government in Bahrain, by issuing a new Telecommunication Law ended the monopoly status of Batelco by letting a Joint Venture between UK Vodafone and the Bahraini division of Kuwaiti's mobile telecommunication to set up a mobile phone company in the Gulf Arab State under the banner MTC Vodafone Bahrain., see more at: www.telegeography.com (30.07.2019).

75 Law of 6 March 2019 on Protection of Competition, see more: http://www.elexica.com/ en/legal-topics/antitrust-and-merger-control/200519-new-ksa-competition-law (30.07.2019). 
the umbrella of the Ministry of Commerce and Industry. ${ }^{76}$ The independent nature of this body has not been topic of discussion. The Law will apply to any natural and legal person engaged in economic activities including commercial, industrial, agricultural etc., in Saudi Arabia and those outside the country breaching its Competition Law within the domestic market. The law applies to all firms working in the Saudi Arabia markets, except for public corporations and wholly owned state companies. ${ }^{77}$ Governmental companies are excluded from its scope of application.

The Law aims to achieve a number of objectives, including: protecting and encouraging fair competition, monitoring and prohibiting practices that might affect fair competition; enhancing the market and regulate all commercial practices in the investment market; protecting small and medium business; protecting the quality of goods and fair prices etc. In general terms, similarly to other jurisdictions, the Law sets wide prohibitions on the three main pillars of competition law namely [Anti]Competitive Arrangements (Agreements), Abuse of a Dominant Position and Concentrations. Concentrations are under a duty to notify within 90 days prior to the completion date if the total turnover of the participating companies exceeds a specific amount (to be determined by implementing regulations). An interesting novelty is that Saudi Arabia allows private actions for damages but not injunctions. ${ }^{78}$

\section{GCC competition law: an avenue for the future?}

As seen so far, companies engaged in business activities within the GCC enjoy certain benefits. These advantages are enshrined in the GCC Economic Agreement. Unfortunately, the GCC Economic Agreement from $1981^{79} \mathrm{did}$ not include provisions on Competition Law. This approach is quite different compared to the European Union regarding the exclusive powers the EU embrace on Competition Law. ${ }^{80}$ Therefore 'joint projects' within the GCC Economic Agreement, comparable to 'joint ventures' at the EU level, may be considered a potential foundation on which a GCC Competition Law can be established. ${ }^{81}$ However, this is not an easy task in a region were lack of

\footnotetext{
76 Articles 8-11 of Law on Protection of Competition.

77 Articles 4-7 of Law on Protection of Competition.

78 Saudi Arabia Competition Law Art. 18; South Korea Fair Trade Act Art. 56 (allowing private damages); see also Elhaug and Geradin, 2011, p. 71.

79 The Economic Agreement of 2001, see more at: www.gcc-sg.org.

80 See Articles 2, 3 and 4 TFEU.

81 Ibidem.
} 
effective enforcement and absence of information from National Competition Authorities (NCAs), including among others, difficulties in providing information in English language, is evident. ${ }^{82}$

However, in practical terms, a number of well-known companies are already operating at the GCC level. This was the case for example with acquisitions including Amazon and Souq.com, Delivery Hero with Talabat and Carrigae etc. ${ }^{83}$ Talabat, as an online delivery service, was established in 2004 in Kuwait and today performs in all GCC Members. ${ }^{84}$ Kuwait is also known as a birth country of Carriage, whose acquisition by Delivery Hero was announced in June 2017, operating as an innovative and fast growing ordering platform from one group of users to another characterized as a two or multi-sided market. ${ }^{85}$ The acquisition was published in the Delivery Hero financial Annual Report, ${ }^{86}$ as the Competition Authority has been silent. ${ }^{87}$ The part discussing Kuwait above provides detailed analysis of these cases. However, is important to mention that today GCC and other Arab countries enjoy the servises provided by these undertakings.

The most known acquisition within GCC is Souq.com, considered a breakthrough in the region (Schroeder, 2017). Souq.com was founded in 2005 and in 2011 changed its model to an online shopping site similar to Amazon. Known as the largest e-commerce platform in the Arab world as of 2016, in 2014 it delivered services to all GCC Member States. ${ }^{88}$ In 2017, Souq.com

82 Their lack of efficiencies is also noticeable in not updating their web-sites or publishing the decisions in the official Gazette, although it is prescribed in some countries as a duty, See for example, the Law on Protection of Competition in Oman, Article 27, or the Law for Protection of Competition in Saudi Arabia, Article 21.

${ }^{83}$ GCC region certanly is not also immune from online giants such as Amazon, Google, Apple, Facebook, etc. They all operate in the region but contrary to the 'hot pros and cons' debate in EU and US, their way of doing bussines is considred rather a privilege to the consumers, than a threat to fair competition, see Galloway, S. (2017). The four: the hidden DNA of Amazon, Apple, Facebook and Google. Random House. See also Akman, P. (2019). Online Platforms, Agency, and Competition Law: Mind the Gap. Fordham International Law Journal, Forthcoming.

84 The case was also mentioned above when discussing Kuwait.

85 See more at: https://www.menabytes.com/carriage-100-million/ (30.07.2019).

86 Delivery Hero, financial report see more https://ir.deliveryhero.com/websites/delivery/ English/3100/financial-reports.html, see also Delivery Hero Annual Report of 2018 see more https:// ir.deliveryhero.com/download/companies/delivery/Annual\%20Reports/Final_secured_en.pdf.

87 The Authority considered that the acquisition of Carriage, which is currently operating in the State of Kuwait and other GCC countries under the Talabat brand, may be harmful to competition in the food delivery market and could potentially result in the monopolization of these services by one operator, see more at Mondaq.com, http://www.mondaq.com/x/636574/ Antitrust+Competition/Competition+Law+Developments + In+Kuwait (30.07.2019).

88 Wall Street Journal Blogs, 'Souq.com, Dubai-Based E-Commerce Site, Retrieved 25 October 2015. 
localized operations in Saudi and Emirates. As of January 2018, Souq.com subsidiaries include their delivery arm such as Q-express, payment platform Payfort, repair and service marketplace - Helpbit, and delivery marketplace Wing. ${ }^{89}$ On May 1st 2019, Souq.com was officially acquired by Amazon and became Amazon.ae..$^{90}$ Today, Amazon.ae, is the only English-Arabic language e-commerce platform, owned by the Amazon Incorporation. ${ }^{91}$

In addition, GCC is not exempt from other companies conducting business in the digital market including Amazon, Google, LinkedIn and Facebook, which have all been expanding their presence in GCC and notably the Middle East (Schroeder, 2017). Amazon, considered a giant within the competition communities, puts under the test the existence of its subsidiaries, such as souq.com.

Finally, as a general remark, it has been reported that mergers within GCC have been notified to Authorities where competition rules seem more lenient than in others. ${ }^{92}$ For example, based on the GCC stock exchanges, while in 201445 mergers were registered between GCC countries in the Emirates, the number jumped to 73 in 2018. In Kuwait the number of mergers reached from 16 in 2014 to 42 in 2018. However, the number of mergers in Saudi was 25 in 2014, decreased to 9 in 2017 and then reached 22 in 2018. This fact once more raises the need to think about leveling the rules and develop a GCC Competition Law.

\section{Conclusion}

Competition law at the EU level at times is considered the heart of the European Union (Nazzini, 2011) as well as the night watchmen of the economy (Slot and Farley, 2017). The directly applicable norms and the institutional infrastructure established within the EU, while far from being perfect, are arguably considered the best developed so far. The model provides a solid foundation for other unions or communities to build the neccessary toolkit towards harmonisation of their competition rules. Having in mind

89 Megaw, N. (2017) 'Amazon confirms Souq takeover in deal to dominate Middle East'. Financial Times. Retrieved April 3, 2017.

90 'Amazon officially launches in UAE, replaces Souq.com'. See also Parasie, N. (2017). 'Amazon to Buy Middle East E-Commerce Site Souq.com'. Wall Street Journal. New York City, New York, United States. Retrieved March 30, 2017; Megaw, 2017.

91 Montini, L. (2015). 'Meet Souq, the Amazon of the Middle East'. Inc.com. Retrieved 21 July, 2016.

92 S\&P Capital IQ, GCC Stock Exchanges, Local Newspapers, Mergers and Acquisition in GCC, 2014-2018. 
that and the potential for further economic growth within the GCC; the further enhancement of competition laws of the individual GCC jurisdictions as well as a potential 'common' GCC Competition Law may be considered paramount in order to maintain and balance these achievements in the region (Pollard, 2014).

Recent developments covering all GCC countries should be commended. All of them have now adopted their respective competition laws. The Competition Law of Bahrain should make progress encouraged by its positive sectorial development. In terms of the institutional framework, Oman in particular should be distinguished with the establishment of the independent Center for Protection of Competition. ${ }^{93}$ Saudi shows improvement moving a step forward in enacting the second Law and paving the way for better enforcement. The undisputed enhancement of trade and investing climate in Kuwait, Emirates and Qatar is in greater need for a more competitive atmosphere in order for consumer welfare to grow to a vital principle.

Therefore, competition law is no longer an unknown notion in the GCC Member States. Although the process is gradual, the legislation drafting phase is closed in the region. ${ }^{94}$ The natural next step will be to enhance the application, which for the time being is considered very weak (Daudpota, 2015). A successful application may serve as an open gate for the development of competition law at the GCC level.

\section{Literature}

Al-Qaisi, M. (2019). Formation and Competition Body and its impact on its Ability to perform its Role under Arab Competition Laws, paper presented on the $6^{\text {th }}$ Annual International Conference, Contemporary Legal Developments, Issues and Challenges, 1-2 May, 2019, Kuwai.

Behrens, P. (2015). The Ordoliberal Concept of'Abuse'of a Dominant Position and its Impact on Article 102 TFEU. In: Nihoul/Takahashi, Abuse Regulation in Competition Law, Proceedings of the 10th ASCOLA Conference Tokyo.

93 Public Authority for Consumer Protection in Charge of Competition Law.

94 Authors note that substantial time is required in order to develop a body of competition law followed by enforcement. The antitrust regime in the United States began with the adoption of the Sherman Act in 1890, enforced by the Department of Justice. This Department needed almost 7 years to successfully defend its application of the Act before the Supreme Court. The Federal Trade Commission on the other hand, formed in 1914, had also a difficult beginning. It did not receive a Supreme Court rulings upholding its broad grant of regulatory authority until the 1960s. See more: Denny, 2017; Kovacic and Lopez-Galdos, 2016, p. 88. 
Akman, P. (2017). The theory of abuse in Google Search: A positive and normative assessment under EU Competition Law. Journal of Law, Technology and Policy, 2, 301-374.

Akman, P. (2009). Searching for the long-lost soul of Article 82EC. Oxford Journal of Legal Studies, 29(2), 267-303, https://dx.doi.org/10.1093/ojls/gqp011.

Akman, P. (2008). Exploitative Abuse in Article 82EC: Back to Basics?. ESRC Centre for Competition Policy CCP Working Paper, 9-1.

Akman, P. (2010). 'Consumer' versus 'Customer': the Devil in the Detail. Journal of Law and Society, 37(2), 315-344, https://dx.doi.org/10.1111/j.1467-6478.2010.00506.x.

Bode, M., \& Budzinski, O. (2005). Competing Ways towards International Antitrust: the WTO versus the ICN, Marburg Economics Working Paper, 3, https://dx.doi.org/10.2139/ ssrn.888682.

Casoria, M, (2017). Competition Law in the GCC Countries: The tale of a Blurry Enforcement, Chinese Business Review, 16, 3, 141-149, https://dx.doi.org/10.17265/15371506/2017.03.003.

Colino, S.M. (2017). Cartels and Anti-Competitive Agreements: Volume I. London: Routledge, https://dx.doi.org/10.4324/9781315260853.

Collins, P., Trebilcock, M.J., Winter, R.A. and Iacobucci, E.M. (eds.) (2003). The law and economics of Canadian competition policy. Toronto: University of Toronto Press, https:// dx.doi.org/10.3138/9781442681606.

Crandall, R.W. and Winston, C. (2003). Does antitrust policy improve consumer welfare? Assessing the evidence. Journal of Economic Perspectives, 17(4), 3-26, https://dx.doi. org/10.1257/089533003772034871 .

Crane, D. (2013). Judicial Review of Anticompetitive State Action: Two Models in Comparative Perspective, Journal of Antitrust Enforcement, 1(2), 418-436, https://doi. org/10.1093/jaenfo/jnt006.

Dabbah, M.M. (2010). International and comparative competition law. Cambridge: Cambridge University Press.

Daudpota, F. (2015). Competition Law in the Kingdom of Saudi Arabia, Riyadh: KSA.

Denny, M. (2019). Application of Rule of Law in Competition Law and Policy: An Analysis of the Delayed Implementation of Competition Law in Kuwait, Kuwait International Law School Journal, Special supplement, 2, 2.

Doleys, T.J. (2012). Promoting competition policy abroad: European Union efforts in the developing world. The Antitrust Bulletin, 57(2), 337-366, https://dx.doi.org/10.1177/00 $03603 \times 1205700205$.

Drauz, G., Chellingsworth, T., and Hyrkas, H. (2009). Recent Developments in EC Merger Control. Journal of European Competition Law \& Practice, 1(1), 12-26, https://doi. org/10.1093/jeclap/lpp004.

Elhauge, E. (2017). United States antitrust law and economics. Foundation Press.

Foster, N. (ed.). (2016). Blackstone's EU Treaties and Legislation 2016-2017 (Vol. 27). Oxford: Oxford University Press.

Fox, E.M. (2015). Antitrust without borders: From roots to codes to networks. Geneva: International Centre for Trade and Sustainable Development (ICTSD).

Fox, E.M. (2006). Economic development, poverty and antitrust: the other path. Southwestern Journal of Law and Trade in the Americas, 13, 211.

Fox, E.M. and Healey, D. (2013). When the State Harms Competition-The Role for Competition Law. Antitrust Law Journal, 79. 
Fox, E.M. and Trebilcock, M.J. (eds.). (2013). The design of Competition Law institutions: global norms, local choices, Oxford: Oxford University Press, https://doi.org/10.1093/acp rof:oso/9780199670048.001.0001.

Gal, M. (2004). The ecology of antitrust: preconditions for competition law enforcement in developing countries. Competition, competitiveness and development: New York University, Law \& Economics Research Paper Series, 20-38.

Gal, M.S. and Fox, E.M. (2015). Drafting Competition Law for developing jurisdictions: learning from experience. In: M.S. Gal, M. Bakhoum, J. Drexl, E M. Fox and D.J. Gerber (eds.). The Economic Characteristics of Developing Jurisdictions: Their Implications for Competition Law, Edward Elgar Publishing, 296-356, https://dx.doi.org/10.4337/97817 83471508.00024.

Geradin, D., Reysen, M., and Henry, D. (2008). Extraterritoriality, Comity and Cooperation in EC Competition Law. Oxford Scholarship Online, https://dx.doi.org/10.2139/ ssrn.1175003.

Gerber, D. (2010). Global competition: law, markets, and globalization. Oxford: Oxford University Press.

Evenett, S.J., Hamouda, F.H., Saleh, H., Barashidi, A. (2019). Cardinal Rules and Provisions of the American Competition Law and its Practices (paper presented on the $6^{\text {th }}$ Annual International Conference, Contemporary Legal Developments, Issues and Challenges, 1-2 May, 2019, Kuwait).

Ghura, H. and Harraf, A. (2018). Entrepreneurship in Kuwait through the Eyes of Global Entrepreneurship Index (GEI) (conference paper: International Conference on Innovation and Economic Diversification in GCC's National Development Plans (IED18), At Arab Open University, Kuwait).

Hawk, B.E. (ed.). (2013). International Antitrust Law \& Policy: Fordham Competition Law 2012 (Vol. 39). Juris Publishing, Inc.

Hyman, D.A., and Kovacic, W. E. (2012). Institutional design, agency life cycle, and the goals of Competition Law. Fordham Law Review, 81(5), 2163-2174.

International Competition Network (2002). Advocacy and Competition Policy. Retrieved from http://www.internationalcompetitionnetwork.org/ (30.07.2019).

Jones, A., and Sufrin, B. (2016). EU Competition Law: text, cases, and materials. Oxford: Oxford University Press.

Kaplow, L. (2011). On the choice of welfare standards in Competition Law. Harvard Law and Economics Discussion Paper, 693, https://dx.doi.org/10.2139/ssrn.1873432.

Kennedy, D. (2018). A world of struggle: How power, law, and expertise shape global political economy. Princeton University Press, https://dx.doi.org/10.1515/9781400880591.

Koppenfels, U. (2015). A fresh look at the EU merger regulation? The European Commission's White Paper 'Towards more effective EU merger control'. Liverpool Law Review, 36(1), 7-31, https://dx.doi.org/10.1007/s10991-015-9163-x.

Kovacic, W. (1997). Getting Started: Creating New Competition Policy Institutions in Transition Economies, Brooklyn Journal of International Law, 23, 403-453.

Kovacic, W. and Lopez-Galdos, M. (2016). Lifecycles of Competition Systems: Explaining Variation in the Implementation of New Regimes, Law and Contemporary Problems, 79, 85-122.

Kovacic, W.E., and Shapiro, C. (2000). Antitrust policy: A century of economic and legal thinking. Journal of Economic perspectives, 14(1), 43-60, https://dx.doi.org/10.1257/ jep.14.1.43. 
Leary, T.B. (2005). Competition Law and Consumer Protection Law: Two Wings of the Same House. Antitrust Law Journal, 72(3), 1147-1151.

Lehmann, A., and Steil, B. (eds.). (2000). Antitrust goes global: what future for transatlantic cooperation? Brookings Institution Press.

Lundqvist, B. (2014). Standardization under EU competition rules and US antitrust laws: The rise and limits of self-regulation. Edward Elgar Publishing, https://dx.doi. org/10.4337/9781781954867.

Molestina, J. (2019). Regional Competition Law Enforcement in Developing Countries, Munich Studies on Innovation and Competition, Vol. 9, Berlin-Heidelberg: Springer, https://dx.doi.org/10.1007/978-3-662-58525-2.

Ghoneim, A.F. (2003). Competition Law and competition policy: what does Egypt really need?. Boletín latinoamericano de competencia, 17, 46-58.

Megaw, N. (2017). Amazon confirms Souq takeover in deal to dominate Middle East. Financial Times (28 March 2017). Retrieved 3 April, 2017.

Montini, L. (2015). Meet Souq, the Amazon of the Middle East' (8 June 2015). Inc.com. Retrieved 21 July 2016.

Nazzini, R. (2011). The foundations of European Union Competition Law: the objective and principles of Article 102. Oxford: Oxford University Press, https://dx.doi.org/10.1093/acp rof:oso/9780199226153.001.0001.

Odudu, O. (2010). The last vestiges of overambitious EU Competition Law. The Cambridge Law Journal, 69(2), 248-250, https://dx.doi.org/10.1017/s0008197310000449.

Palacios-Lleras, A. (2010). The Uneasy Case for Enforcing Competition Law Provisions Related with Excessive and Unfair Prices in Developing Countries. Revista de la Maestría en Derecho Económico, 6(6), 457-489.

Parasie, N. (2017). Amazon to Buy Middle East E-Commerce Site Souq.com. Wall Street Journal (March 28, 2017). Retrieved 30 March 2017.

Petersmann, E.U. (1999). Legal, Economic and Political Objectives of National and International Competition Policies: Constitutional Functions of WTO Linking Principles for Trade and Competition. New England Law Review, 34, 145.

Pollard, M. (2014). More Than a Cookie Cutter: the Global Influence of European Competition Law, Journal of European Competition Law \& Practice, 5(6), pp. 329-330, https://doi.org/10.1093/jeclap/lpu050.

Qaqaya, H. and Lipimile, G. (eds.) (2008). The effects of anti-competitive business practices on developing countries and their development prospects, New York and Geneva: United Nations Conference on Trade and Development. Retrieved from: https://unctad.org/en/Docs/ditcclp20082_en.pdf (30.07.2019).

Rakic. I., (2016) Competition Authorities in South Eastern Europe. In: B. Begovic, D. Popovic (eds.). The Role of Competition Advocacy: The Serbian Experience. Springer, 111-132, https://doi.org/10.1007/978-3-319-76644-7.

Slot, P.J. and Farley, M. (2017). An Introduction to Competition Law. Bloomsbury Publishing.

Stucke, M.E. (2013). Is competition always good? Journal of Antitrust Enforcement, 1(1), 162-197, https://dx.doi.org/10.1093/jaenfo/jns008.

Schroeder, Ch.M (2017). A Different Story from the Middle East: Entrepreneurs Building an Arab Tech Economy. MIT Technology Report.

Svetlicinii, A. (2006). EU-US Merger Control Cooperation: a Model for the International Antitrust?. Legal Life: Journal for Legal Theory and Practice of the Jurists Association of Serbia, 11, 113-126. 
Waked, D.I. (2014). Antitrust goals in developing countries: policy alternatives and normative choices. Seattle University Law Review, 38, 945.

Waked, D. (2008). Competition Law in the developing world: The why and how of adoption and its implications for international Competition Law. Global Antitrust Review, 1, 69-96.

Watson, A. (1994). Legal Transplants: An Approach to Comparative Law, University of Georgia Press.

Whish, R. and Bailey, D. (2018). Competition Law. Oxford University Press, https://dx.doi. org/10.1093/law-ocl/9780198779063.001.0001.

Whelan, P. (2014). The criminalization of European cartel enforcement: Theoretical, legal, and practical challenges. Oxford: Oxford University Press, https://dx.doi.org/10.1093/acp rof:oso/9780199670062.001.0001.

Vedder, H. (2006). Competition Law and Consumer Protection: How Competition Law Can Be Used to Protect Consumers Even Better - Or Not? European Business Law Review, 17(1), 83-93. 